\title{
Features of management of objects of protected areas in urbanized territories
}

\author{
Alexander Kryahtunov ${ }^{1}$, Olga Bogdanova ${ }^{1}$, and Elena Chernykh ${ }^{1, *}$ \\ ${ }^{1}$ Industrial University of Tyumen, 625001, Tyumen city, Russia
}

\begin{abstract}
Tyumen region is a complex subject of the Russian Federation. Management of specially protected natural areas in this region has a number of features. In this article the example of legal contradiction and complexity of decision-making in cases of development of oil and gas fields and preservation of object of especially protected natural territories is considered
\end{abstract}

\section{Introduction}

One of the features of the Russian Federation is the presence of large-scale areas of protected natural areas. Tyumen region is the only region of Russia stretching from the Arctic ocean in the North to the state border in the South. This is one of the richest natural resources area. The Tyumen region, taking into account the Khanty-Mansiysk and YamaloNenets Autonomous districts, includes more than 130 specially protected natural areas (SPNA) of Federal, regional and local significance, which occupy a total area of $11,552,961.7$ hectares, which is $8 \%$ of the entire territory of the composite subject of the Russian Federation (table. 1). [8]

Table 1.Information on the distribution of protected areas within the Tyumen region.

\begin{tabular}{|c|c|c|c|}
\hline Name of entity & Total area. $\mathbf{~ k m}^{\mathbf{2}}$ & $\begin{array}{c}\text { Area of reserves. } \\
\mathbf{k m}^{\mathbf{2}}\end{array}$ & $\begin{array}{c}\text { Share in land Fund. } \\
\mathbf{\%}\end{array}$ \\
\hline $\begin{array}{c}\text { Yamalo-Nenets } \\
\text { Autonomous Okrug }\end{array}$ & 750300 & 78965.2 & $10.5 \%$ \\
\hline $\begin{array}{c}\text { Khanty-Mansi } \\
\text { Autonomous Okrug }\end{array}$ & 534800 & 27564.4 & $5.2 \%$ \\
\hline $\begin{array}{c}\text { South of Tyumen } \\
\text { region }\end{array}$ & 149900 & 9000 & $6 \%$ \\
\hline Subtotal & 1435000 & 115529.6 & $8 \%$ \\
\hline
\end{tabular}

The dynamics of the distribution of protected areas in the Tyumen region by management levels for 2016-2019 is shown in figure 1.

\footnotetext{
* Corresponding author: chernyheg@tyuiu.ru
} 
$\square$ Federal protected areas $\square$ protected areas of regional importance $\square$ local protected areas

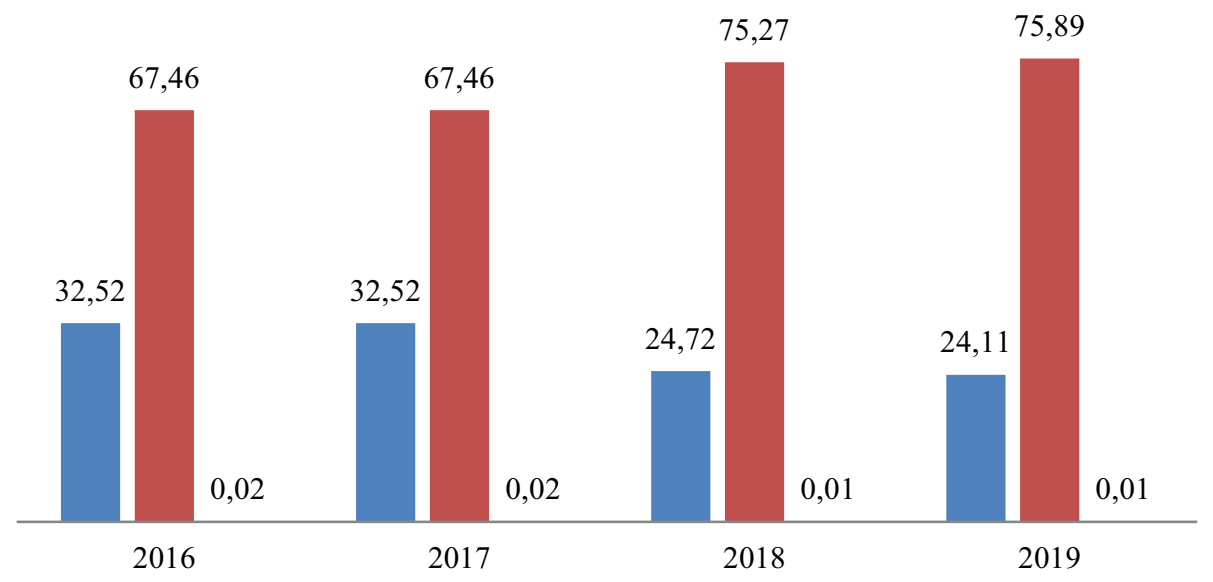

Fig. 1. Dynamics of protected areas of the Tyumen region by management levels, (\%) (authoring).

Thus, it becomes obvious that the Tyumen region is dominated by protected areas of regional importance, which determines the main vector of development of the protected areas.

The current system of specially protected areas of the Tyumen region is unique, this is due to the following regional features:

1.The Tyumen region is a complex entity with a complex scheme of territory management and financing (on the basis of the decision of the constitutional court of July 14, 1997, the fact of entering the Autonomous districts into the Tyumen region was confirmed, but the equality of these entities was also recognized);

2. The subject of the Russian Federation is located in 3 natural zones-forest-steppe, taiga, tundra, which in turn include subzones characterized by diverse flora and fauna, landscape, climate and other features.;

3. Remoteness and inaccessibility of certain territories of the region, lake-swampy terrain, severe climatic conditions and the prevalence of low temperatures, permafrost, tundragley soils with a low rate of natural recovery;

4. The presence of the largest oil and gas reserves (about $70 \%$ of the annual volume of oil production in Russia falls on KHMAO and Yamal, KHMAO and Yamal-1, 2 place among all regions of Russia in oil reserves, respectively, Yamal-1 place in gas production);

5. Resource and raw material potential is a modern model of development of the Far North. Large-scale development of natural resources leads to a multilateral impact on natural-territorial complexes, including both pollution of environmental components and geomechanical impact on soils and vegetation, activation of geocryological processes, etc.;

6. Saturation of the territory with engineering communications, which determine the predominance of the linear type of land disturbance and change in the hydrological regime; large area coverage of oil and gas fields, land pollution with oil and gas products, technical solutions, litter;

7. The use of land by indigenous peoples, leading traditional crafts, agricultural production

This list of features of the territory is not exhaustive, but these factors have a direct and significant impact on the functioning and creation of protected areas. 


\section{Materials and methods}

The system of protected areas is characterized by the following features:

1. A fairly stable system of protected areas has developed in the Tyumen region, which confirms a slight change in the area $(1.5 \%)$ of such territories over the past 5 years (upward).

2. Protected areas of regional importance prevail in the study area, they make up $76 \%$ of the total area of especially valuable territories of the region. As noted earlier, about $87 \%$ of protected areas located in the country have regional status. This can be explained by the fact that, first of all, the state authorities of the subject have great powers to ensure the preservation of the unique ecosystem of a particularly valuable natural complex, landscape within the boundaries of the subject. However, the legislation does not establish a clear system of criteria for dividing protected areas into levels of value and category.

3. Currently, there are 9 federal protected areas in the Tyumen region $(23.9 \%$ of the total protected area), of which 4 are state nature reserves located in the autonomous okrugs of the region, as well as 5 state nature reserves.

4. Despite the large number of regulatory acts in the field of protected areas, including those developed at the regional level, today there is a certain number of gaps in the legal regulation of such relations, which entails the violation and loss of the unique properties of natural complexes.

5. In the territory of Khanty-Mansi Autonomous Okrug and the Yamalo-Nenets Autonomous Okrug, territories of traditional nature management have been historically formed, which are currently excluded from the categories of protected areas, therefore they are actively used for economic development, despite the fact that they are often located within the boundaries of specially protected territories and are also the place of residence of small peoples North and determine their ethnic uniqueness (Decree of the Government of the Khanty-Mansi Autonomous Okrug-Ugra,2013).

6. Wetlands are a separate category of protected areas established at the level of the Khanty-Mansi Autonomous Okrug and the Yamalo-Nenets Autonomous Okrug, however, their legal regime allows for economic activities within their borders, which leads to the destruction of the natural landscape, a change in the hydrological regime, etc. In the Khanty-Mansi Autonomous Okrug, wetlands of international importance were formed - the Lower Dvoobye, one of the sites is located on the territory of the Khanty-Mansi Autonomous Okrug - Ugra, two more in the Yamalo-Nenets Autonomous District and the Upper Dvuobye, located in the Oktyabrsky district of the Khanty-Mansi Autonomous Okrug, having an area of 540 and 470 thousand ha, respectively. Due to the fact that within the boundaries of these lands it is allowed to carry out economic activities, the territories are subject to pollution by waste, violation of soil, vegetation cover, hydrological regime. Yamal-Nenets Autonomous Okrug and Khanty-Mansi Autonomous Okrug has great potential for the development of wetlands; according to the data, the prospective area of such territories is 3974 thousand ha.

7. Protected areas are located not only within the category of lands of specially protected territories of objects, but also on the lands of settlements, forestry, water funds, agricultural purposes, the legal regime of which does not always ensure their preservation.

Thus, based on the foregoing, a number of difficulties arise when managing PAs of various nature, let us consider as an example of management the Sorumsky state nature reserve of regional importance located in the Khanty-Mansi Autonomous Okrug-Yugra. (fig. 2). 


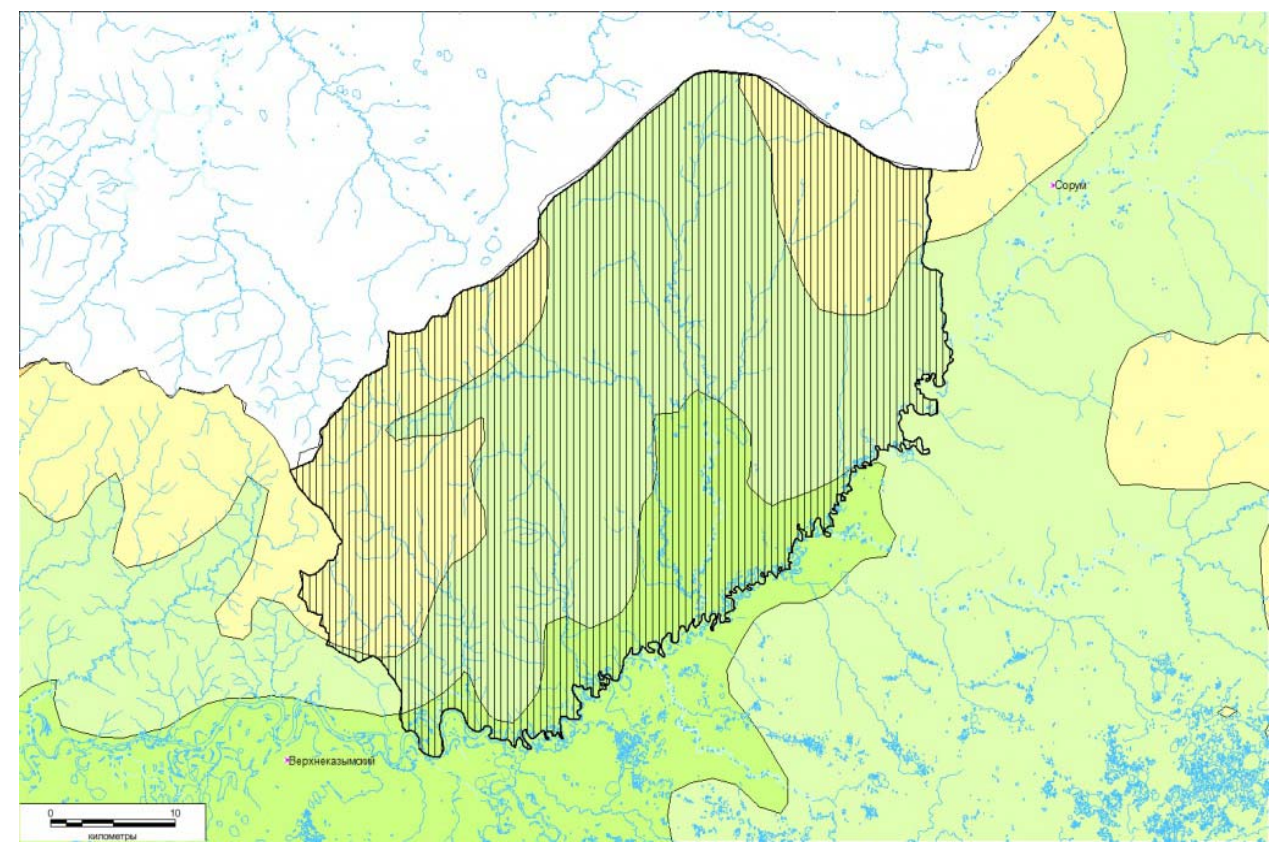

Fig. 2. Reserve boundary «Sorumsky».

\section{Results}

In 2014, geological surveys and exploration for the extraction of mineral resources began on the territory of the reserve, after which they received a license for drilling and oil production. According to the order of Uralnedr dated July 02, 2014 No. 245 "On approval of the results of the auction for the right to use the subsoil of the Separate site for the purpose of geological exploration, exploration and production of hydrocarbons in the territory of the Khanty-Mansiysk Autonomous Okrug-Ugra", the Open Joint-Stock Company became the winner of the auction ( OJSC) Gazpromneft-Noyabrskneftegaz. GazpromneftNoyabrskneftegaz is a subsidiary of Gazprom Neft and is engaged in oil production in the Khanty-Mansiysk Autonomous Okrug and in the Yamalo-Nenets Autonomous Okrug.

Since the Otdelny site is located in the territory that is the traditional nature management of the indigenous population, the oil company needed, according to regional legislation, to coordinate the placement of industrial facilities with them. A separate field is located in the territory of traditional nature management located in the Sorumsky reserve.

The result of the negotiations was a categorical refusal of the Khanty community to locate industrial facilities. The reason for the refusal was the fact that the development of the field will lead to a narrowing of the area of nature management and a number of other negative consequences. In particular, the size of the territory directly affects the size of the herd. Deers feed on grasses and reindeer moss, which grows very slowly, and in order to feed animals, it is necessary to distill them over a vast territory. Thus, a reduction in the area of nature management will lead to a decrease in the number of animals. Another reason was the environmental side of the issue. Pipe breaks and oil spills often occur in the fields, polluting the soil and depriving deer of food. The territory of traditional nature management S$14 \mathrm{P}$ is located on the watershed at the mouth of the river and this means that water that is drunk by animals and people will suffer, far beyond the boundaries of this territory. In addition, the taiga is also littered with household waste. 
In the case of negative approval or refusal by the subjects of the right to use traditional nature management of a scheme for placing industrial facilities, Article 12 of Chapter 4 of the Law of the Khanty-Mansiysk Autonomous Okrug - Ugra "On Territories of Traditional Nature Management of Indigenous Minorities of the North of Regional Importance in the Khanty-Mansiysk Autonomous Okrug - Ugra" prescribes " ... location options and accommodation conditions for industrial and other related facilities are considered by the Territorial Commission traditional nature management, which prepares relevant recommendations to the Government of the Autonomous Okrug. The Government of the Autonomous Okrug, taking into account the recommendations of the Commission, may decide to either approve or refuse to agree on a scheme for placing objects within the boundaries of the territory of traditional nature management. "Thus, in accordance with the legislation, OAO Gazpromneft - Noyabrskneftegaz received an appeal on the fact that there was no solution to the issue of approving the scheme placement. And on January 20, 2015 in the city of Noyabrsk, a meeting of the Commission on the territories of traditional nature management was held at which this issue was discussed. As a result of the meeting, the Government adopted the following order, as well as agreed on the layout of the field.

\section{Discussion}

Thus, despite the attempts of protest by the indigenous people, the layout of industrial and other related facilities was agreed by the Okrug Government and the field is being developed.

The indigenous peoples of the Server are in such a position that they cannot refuse an oil company to extract minerals on their territory. In view of the fact that after obtaining a license to develop a licensed site, the company of subsoil users has legal grounds for using the site. And no matter what measures the indigenous people try to take, they do not bring results, since the laws do not provide for the possibility of refusal for them. The main legal act of the Russian Federation - the Constitution "guarantees the rights of indigenous peoples in accordance with generally recognized principles and norms of international law and international treaties". The main laws in relation to the indigenous population are Federal Law No. 82-Ф3 “On Guarantees of the Rights of Indigenous Minorities of the Russian Federation" and Federal Law No. 49-FZ "On Territories of Traditional Nature Management of Indigenous Minorities of the North, Siberia and the Far East of the Russian Federation". According to these laws, protection should be provided for the native habitat and traditional way of life of small peoples. And the sizes of territories of traditional nature management should be determined taking into account the maintenance of sufficient populations of plants and animals to ensure renewability and conservation of biological diversity.

\section{Conclusion}

Nevertheless, the interests of oil and gas companies often come first, since the stability of the country's economy depends on the volume of hydrocarbon production, and local governments depend on their financing. And all the protection of the primordial living environment and the preservation of the traditional way of life is to buy from the indigenous population by providing them with various benefits and money. Which, of course, does not help maintain their traditional way of life. Based on the foregoing, the following problems can be formulated:

1. Coordination of the layout of industrial and other facilities, in certain cases, may occur without taking into account the views of indigenous peoples; 
2. No calculation is made of the damage to the original environment of indigenous peoples caused by subsoil users as a result of their activities;

3. The Federal Laws "On Guarantees of the Rights of Indigenous Minorities of the Russian Federation" and "On the Territories of Traditional Nature Management of Indigenous Minorities of the North, Siberia and the Far East of the Russian Federation" with respect to the protection of the native environment are not respected.

In conclusion, it should be noted that the preservation and development of culture, identity and traditions make it possible to use land and biological resources in accordance with the complex cultural customs of indigenous peoples. One of the ways to accomplish this task may be to develop a procedure for compensation for damage, which minimizes the negative consequences of the impact on the environment of the territories of traditional nature management and the impact of changes in the original environment and sociocultural situation on the development of an ethnic group.

\section{References}

1. Atlas of specially protected areas of federal and medium importance in the KhantyMansiysk Autonomous Okrug - Ugra (NAO Siberian Research and Analytical Center, 2015)

2. O.V. Bogdanova, E.G. Chernykh, A.V. Kryakhtunov, Zonas naturales especialmente protegidas como objeto de actividad inversora 39(16), $36 \quad$ (2018) http://www.revistaespacios.com/a18v39n16/a18v39n16p36.pdf

3. Decree of the Government of the Tyumen region dated January 16, 2012 No. 8-p

4. Decree of the Government of the Khanty-Mansi Autonomous Okrug-Ugra dated July 12, 2013 No. 245-p

5. A.A. Varlamov, The Economy and ecology of land use. The Formation and justification of objects of land management (OOO publishing house "Folium", M., 2015)

6. S. A. Galchenko, The Theoretical and methodological basis of the effectiveness of the state land cadastre (GUZ, M., 2003)

7. Regions of Russia. Socio-economic indicators. 2017: Stat. Sat (Rosstat., M., 2017)

8. Report on the environmental situation in the Yamalo-Nenets Autonomous Okrug in 2017 (Salekhard, 2017) 